\title{
BALANCED SCORE CARD AS A TOOL FOR IMPROVING EFFICIENCY, PRODUCTIVITY AND QUALITY OF SERVICE IN CABLE OPERATORS
}

\author{
Aleksandar Ristovski, Aleksandar Risteski \\ Faculty of Electrical Engineering and Information Technologies, \\ "Ss. Cyril and Methodius" University in Skopje, \\ Rugjer Bošković bb, P.O. box 574, 1001 Skopje, Republic of Macedonia \\ aleks250@yahoo.com
}

\begin{abstract}
A b s t r a c t: Organizational management is based on the basic principles: planning, organizing, motivating, coordinating and controlling. Proper (optimum) use of the work force, the introduction of control mechanisms, and the introduction of a Balanced Score Card (BSC) can seriously affect the increase in the efficiency and productivity of organizations and contribute to increasing their revenue. Managers' teams are up to the challenge to optimize resources for work, improve quality of work, increase profits, increase productivity and efficiency of the organization, i.e. to perform a greater amount of work with the optimum number of employees, while not sacrificing the quality of the work done.
\end{abstract}

Key words: balanced score card (BSC); human resource management; cable operator

\begin{abstract}
БАЛАНСИРАНА КАРТА НА ОЦЕНА КАКО АЛАТКА ЗА ЗГОЛЕМУВАЊЕ НА ЕФИКАСНОСТА, ПРОДУКТИВНОСТА И ПАРАМЕТРИТЕ ЗА КВАЛИТЕТ НА СЕРВИС ВО КАБЕЛСКИ ОПЕРАТОР
\end{abstract}

\begin{abstract}
А п с т р а к т: Менаџментот на организациите се заснова на основните начела: планирање, организирање, мотивирање, координирање и контролирање. Правилното (оптималното) користење на работната сила, воведувањето на контролните механизми, како и воведувањето на балансираната карта на оцена (БКО), можат сериозно да влијаат врз зголемувањето на ефикасноста и продуктивноста на организациите и да придонесат за зголемување на нивните приходи. Менаџерските тимови се исправени пред предизвикот како да ги оптимизираат ресурсите за работа, да го подигнат квалитетот на работењето, да го зголемат профитот, да ја зголемат продуктивноста и ефикасноста на организацијата, т.е. со оптимален број вработени да сработат поголем обем на работа, притоа не жртвувајќи го квалитетот на сработеното.
\end{abstract}

Клучни зборови: балансирана карта на оцена (БКО); управување со човечки ресурси; кабелски оператор

\section{INTRODUCTION}

The Balanced Score Card (BSC) is a system for strategic planning and management of organizations in order to improve internal and external connection in the organization, to monitor its position in order to fulfill its strategic goals and development [1]. The goal is to show how with proper (optimal) use of the work force, by introducing control mechanisms and introducing BSC, the results in the work can be significantly improved. The efficiency and productivity of the operator depends not only on the number of employees it has, but also on the way they are organized and motivated. The quality of service (QoS) parameters, and above all the thoughts of the satisfaction of its users, depend directly on the availability of its service, i.e. in which period of time the user can use the services of the operator uninterruptedly (television, internet and telephony). In addition to increasing the efficiency and 
productivity of its employees, BSC seriously influences the performance of the operator's network, i.e. in stabilizing the network. BSC as a tool for motivating employees can be widely used in many companies that have a large number of employees. Certainly, depending on the area in which the companies deal with, the parameters will be appropriately defined, but the essence of measuring the results is the same, the image that management receives for each employee is the same and the possibility that each employee receives for career development is the same. The goals and parameters of the BSC are derived from the organization's strategy, i.e. they should not be ad hoc inserted, but should be correlated with the mission and the strategy of the organization. The combination of all parameters should be a balance between the results achieved and the desired results.

Balanced Score Card, as a new concept, was first published in a Harvard Business Review article in 1992. It is based on a one-year research project run by the Nolan Norton Institute and based on research done in twelve successful organizations on the topic "Measuring Organizational Performance in the Future" [2]. The research is conducted by Robert S. Kaplan (Harvard Business School) and David P. Norton, executive director of the Nolan Norton Institute [3]. Robert S. Kaplan and David P. Norton met with representatives of twelve organizations twice a month in order to create a new system for measuring organizational performance [3]. The goal of the project was how to measure the performance of organizations' operations, not just through traditional financial accounting indicators, but also through the value of intangible resources they believed to play a central role in creating organizational value. The principle of this project was that everything that can be valued, i.e. measure, can be improved. Robert S. Kaplan and David P. Norton believed that everything that can be valued is fundamental to both managers and scientists. If organizations can improve the management of intangible resources.

To accomplish these goals, it is necessary:

1. To provide equal opportunity to all career development staff within the organization itself by measuring the single indicators for both the teams and each employee. In this way, each employee knows his place in the BSC ranking.

2. To provide an objective assessment of each employee in a channeled team culture, not as strong solo players, i.e. individuals.

3. To provide additional income to the salary of each employee as a reward for the BSC ranking which is a motivation for better and more successful individual and team work for the employees.

4. Show single and clear goals to strive for.

5. Give us information on how well we do our work according to the expectations and requirements of the company.

6. Give us information on how our users evaluate our work (through the so-called Customer Satisfaction Surveys).

Prior to initiating the application of the BSC, it is presented to all stakeholders (technicians and dispatchers), because the basic idea is that the Balanced Scorecard is the basis for the further evaluation of the employees. Of course, no one can be described with a figure, i.e. there is no ideally made system that will outline the operation of people by number. So, aware that BSC is not an ideal system, the basic idea at the beginning was to point out it's not ideality, but also to present our commitment to continually upgrading and improving it. The practice will show that group and significant changes in the parameters have been made on several occasions, which will contribute to a more realistic representation of the true picture.

The basic principles of the Balanced Score Card are:

1. All employees work in the same conditions, with equal workload, work with the same equipment and serve the same users. They therefore have exactly the same working conditions!

2. Parameters are measured in the same way for everyone, i.e. the same data processing software is used, so "not the accuracy of BSC" is all about the same!

3. The results are always transparent and anyone can check their individual achievements vis-avis the achievements of the entire team.... There is a greater influence of the participants themselves in the creation of the changes and its improvement!

The model itself is not sufficient if it does not exactly define all the parameters that will be monitored every day, which will be their weight coefficients, how these parameters will be interconnected, etc. The goal is to establish a system through which the strategic goals and parameter has an appropriate weight of 10 points in the final calculation.

Repeated ticket (installation): The number of interventions on the field where the first 30 days before the installation was completed successfully, was examined on the total number of successfully completed installations. This parameter has an appropriate weight of 10 points in the final calculation. 
Team results are a set of three parameters:

Productivity: The number of tasks carried out in one region, each task being multiplied by an appropriate weight coefficient (depending on the complexity of the task, the number of technicians who perform the task (one or two), the type of task ...), the number of working hours from the respective region for the given period. This parameter has an appropriate weight of 15 points in the final calculation.

Customer satisfaction: The percentage of satisfied users of the total surveyed users for the respective region. This parameter has an appropriate weight of 10 points in the final calculation.

Independence to user: The percentage of dissatisfied users from the total surveyed users for the respective region. This parameter has an appropriate weight of 5 points in the final calculation.

The assessment by the immediate manager is a set of two parameters:

Disciplinary / Work in the team: The manager assesses how the technician adheres to the work procedures set by the company, how it relates to users and the means of work, whether it is teamset ... This parameter has an appropriate weight of 10 points in the final calculation.

Technical acceptance: The manager assesses the technical readiness of the technician, i.e. how quickly and effectively he can perform tasks of all kinds. This parameter has an appropriate weight of 10 points in the final calculation.
In the maximum number of points that can be earned on a monthly basis, individual scores affect 50 points $(50 \%)$, team scores with 30 points $(30 \%)$ and grade by the manager with 20 points $(20 \%)$, i.e. the maximum is 100 points per month.

From the above we can see that each task is related to the weight coefficient, depending on the complexity of the task and the time it takes to realize it. But weight ratios also depend on the goals of the organization and the direction of management. Depending on what management wants to achieve, the coefficients, i.e. if we want to achieve a higher workload with satisfactory quality, then we give more weight to the productivity

The first three parameters aim to educate all those who have worked on "old glory" until then, and they were absent from work when they liked it. The last parameter is aimed at encouraging the right workers and all those who look long-term as employees in a company that has strictly and equally valid rules for work.

The figures below show the original layout of the spread sheet used to process the parameters required for the monthly calculation of the BSC. This table lists all information entered by the dispatcher when running the team. For example, there is: a task completion date, who typed it, who performed it, a task type, whether it was done by one or two technicians, and complexity of the task, which user is the intervention, which comment is closed the ticket, etc. Correctly filling this table, i.e. the correct input of data by the operator is essential for the correct calculation of the monthly BSC and is the basis for all reports related to BSC.

\begin{tabular}{|c|c|c|c|c|c|c|c|}
\hline Реон 1 & Град & диспечер & $\checkmark$ Дата & борој на запис $\rightleftharpoons$ Слож. & VПланираност & $\nabla 5 p .74 a c=$ & Адреса на клиенто1 7 Име на клиентот \\
\hline Jyг & Прилеп & & 01.12 .2011 & 396730 ниска & Планирана & $\begin{array}{ll}1 & 15: 29\end{array}$ & \\
\hline Запад & Скопје запад & & 01.12 .2011 & 394768 ниска & Планирана & $111: 10$ & \\
\hline Запад & Скопје запад & & 01.12 .2011 & 396090 ниска & Планирана & $211: 11$ & \\
\hline Запад & Скопје запад & & 01.12 .2011 & 396328 ниска & Планирана & $3 \quad 11: 12$ & \\
\hline Запад & Скопје запад & & 01.12 .2011 & 396174 ниска & Планирана & $4 \quad 11: 12$ & \\
\hline Запад & Скопје запад & & 01.12 .2011 & 396313 ниска & Планирана & $\begin{array}{ll}5 & 14: 39 \\
\end{array}$ & \\
\hline Запад & Скопје запаг & & 01.12 .2011 & 394444 ниска & Планирана & $112: 14$ & \\
\hline Запад & Скопје запад & & 01.12 .2011 & 395263 ниска & Планирана & $\begin{array}{ll}2 & 12: 15\end{array}$ & \\
\hline Запад & Скопје запад & & 01.12 .2011 & 395252 ниска & Планирана & $\begin{array}{ll}3 & 12: 15\end{array}$ & \\
\hline Запад & Скопје запад & & 01.12 .2011 & 395249 ниска & Планирана & $\begin{array}{ll}4 & 12: 16\end{array}$ & \\
\hline Запад & Скопје запад & & 01.12 .2011 & 395641 ниска & Планирана & $\begin{array}{ll}5 & 12: 16\end{array}$ & \\
\hline Запад & Скопје запад & & 01.12 .2011 & 393483 ниска & Планирана & $\begin{array}{ll}6 & 12: 17\end{array}$ & \\
\hline Запад & Скопје запад & & 01.12 .2011 & З96646 ниска & Планирана & $1 \quad 19: 38$ & \\
\hline Запад & Скопје запад & & 01.12 .2011 & 396567 ниска & Планирана & $\begin{array}{ll}2 & 19: 39\end{array}$ & \\
\hline Запад & Скопје запад & & 01.12.2011 & 396139 ниска & Планирана & $3 \quad 21: 20$ & \\
\hline Запад & Скопје запад & & 01.12 .2011 & 396699 ниска & Планирана & $\begin{array}{ll}4 & 21: 21\end{array}$ & \\
\hline Jyr & Велес & & 01.12 .2011 & 396853 висока & Планирана & $1 \quad 15: 49$ & \\
\hline Запад & Скопје запад & & 01.12 .2011 & 391055 ниска & Планирана & \begin{tabular}{l|l|}
1 & $10: 25$ \\
\end{tabular} & \\
\hline Запад & Скопје запад & & 01.12 .2011 & 393638 ниска & Планирана & 2 10:25 & \\
\hline
\end{tabular}

Fig. 1a. Working table for the calculation of BSC among field teams 


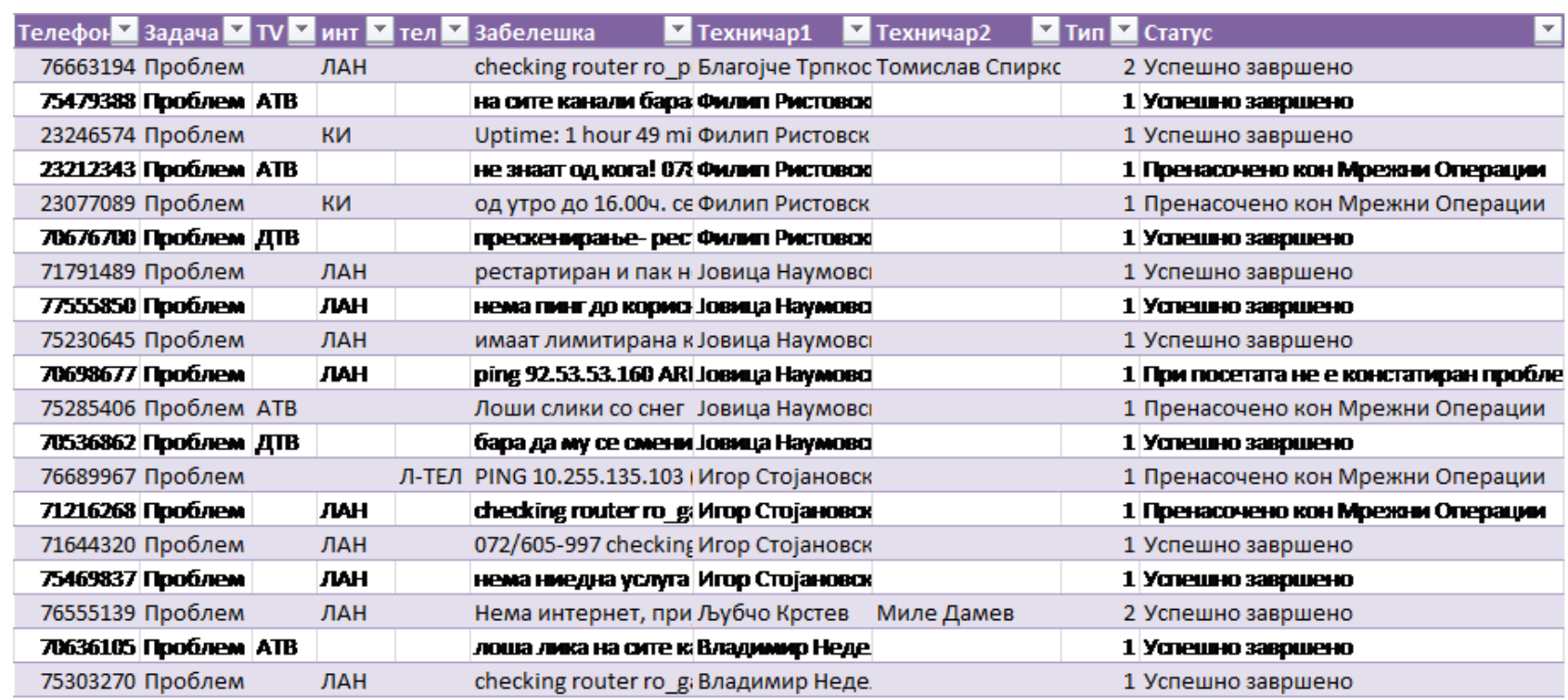

Fig. 1b. Working table for the calculation of BSC among field teams

\section{RESULTS FROM THE 6-YEAR APPLICATION OF THE BALANCED SCORE CARD}

A period of 6 years, 2011 to 2016, has been considered. The goals set are not only achieved, but they are also overwhelmed. The main focus was to introduce order and discipline through a system for objectively measuring and evaluating an employee's performance. Once this is achieved, the results themselves will come back.
However, the main goal is to increase the company's profit. The increase in profits depends directly on improving more measurable parameters, which are:

- then they should be subject to measuring organizational performance.

The following table shows the historical development of the BSC:

Table 1

Historical development of the BSC

\begin{tabular}{|c|c|c|}
\hline Year & Literature & Development of BSC \\
\hline 1992 & $\begin{array}{l}\text { "The BSC: Measures that Drive } \\
\text { Performance" }\end{array}$ & Balance between financial and non-financial indicators. Concept with four perspectives \\
\hline 1993 & "Putting the BSC to Work" & Linking measures with organizational strategy \\
\hline \multirow{6}{*}{1996} & $\begin{array}{l}\text { "Using the BSC as a Strategic } \\
\text { Management System" }\end{array}$ & Four management processes: \\
\hline & & - Translating the vision \\
\hline & The BSC: & - Communication and connectivity \\
\hline & Translating Strategy into Action & - Business planning and goals \\
\hline & & - Feedback and learning \\
\hline & $\begin{array}{l}\text { "Linking the Balanced Score- } \\
\text { card to Strategy" }\end{array}$ & \\
\hline 1999 & $\begin{array}{l}\text { The Strategy Focused Organiza- } \\
\text { tion }\end{array}$ & A higher emphasis on BSC as the basis of the management system \\
\hline 2000 & $\begin{array}{l}\text { "Having Trouble with Your } \\
\text { Strategy" Then Map It. }\end{array}$ & Introducing "strategic maps" \\
\hline \multirow{2}{*}{2004} & \multirow{2}{*}{ Strategy Maps } & Expanding the role of BSC in the strategic process with the concept of a "strategic map" \\
\hline & & How to create, manage and communicate organizational strategy \\
\hline 2005 & $\begin{array}{l}\text { The Office of Strategy Manage- } \\
\text { ment }\end{array}$ & Creation of a new corporate department, a strategic management office \\
\hline
\end{tabular}




\section{BALANCED SCORE CARD - PRACTICAL APPLICATION IN CABLE OPERATOR}

BSC was first implemented in cable operator in 2011. Its main goal is to represent a system through which employees' efficiency and productivity will be increased, a distinction between better and less quality employees would be made, employees would have the opportunity for monthly bonuses, and with this they would be far more motivated to work.

The main goal is, of course, the company to reduce its operating costs by properly and properly reducing the number of employees and by reducing unnecessary costs caused by poor quality of work and inadequate control of daily work tasks.

\section{CONCLUSION}

There is not a sufficiently perfect method that will impeccably bring order and discipline into an organization; there is no single figure that will evaluate the work of the individual and the team without a magic wand with which we can create a favorable climate for a fair and equal competition between the employees, but the Balanced Score Card, with all its faults, showed that it is a method very close to the ideal one. It's a good method for the employee, because it provides a number-based reliability, and for the company, because it can recognize the right workers. The method is easily applicable in any organization where there is an operational team that performs every day tasks. It can be: a health institution, an administrative facility, a contact center, a telephone sales center, etc. It is important to just define the parameters that we want to measure and improve, to find an appropriate connection between them, to control whether this connection is right or not, to be transparent with all employees and they know our ultimate goal and of course we have the support of the senior management in conducting all of this

\section{REFERENCES}

[1] DeWaal. A. A., \& Nhemachena. Z. W.: Building employee trust in performance management: The case of mining company in Zimbabwe. International Journal of Organizational Behavior, 11 (1), 1-19, ISSN 1440-5377.

[2] Kaplan. S. Robert: Conceptual Foundations of the Balanced Score Card., Harvard University, Harvard Business School, Harvard, 2010.

[3] Kaplan. S. R., \& Norton. P. D.: Translating Strategy into Action the Balanced Scorecard. Harvard Business School Press, Massachusetts and Boston, 1996.

[4] Internal data from Cable Operator from the field of the telecommunications sector. 2011-2016.

\section{APPENDIX}

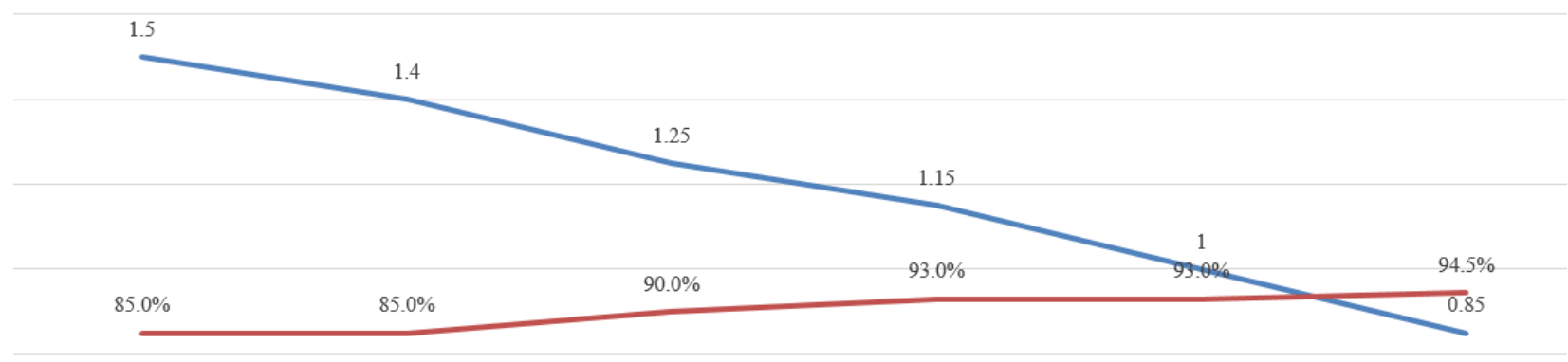

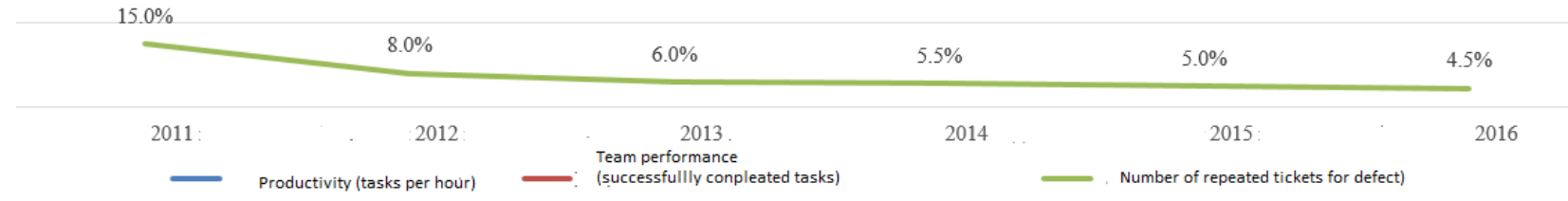

Fig. 2. Counter balance between 3 parameters (productivity, team performance and repeated tickets) 
14,000

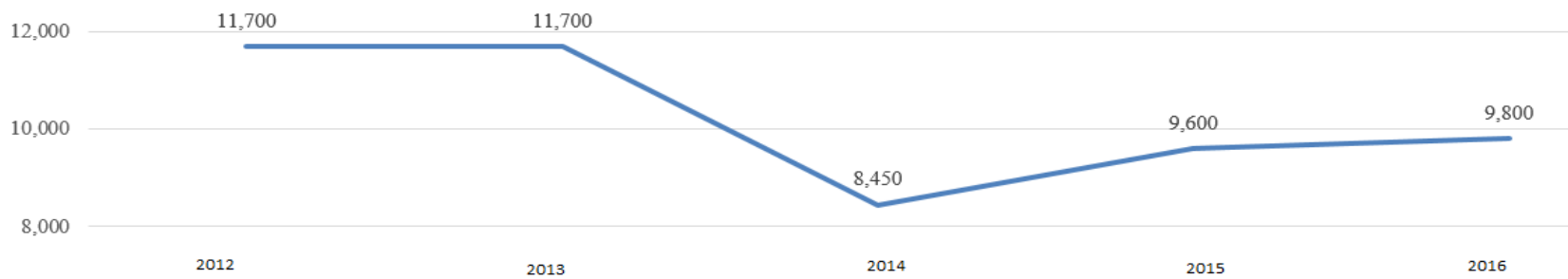

Fig. 3. Unnecessary outings on the field

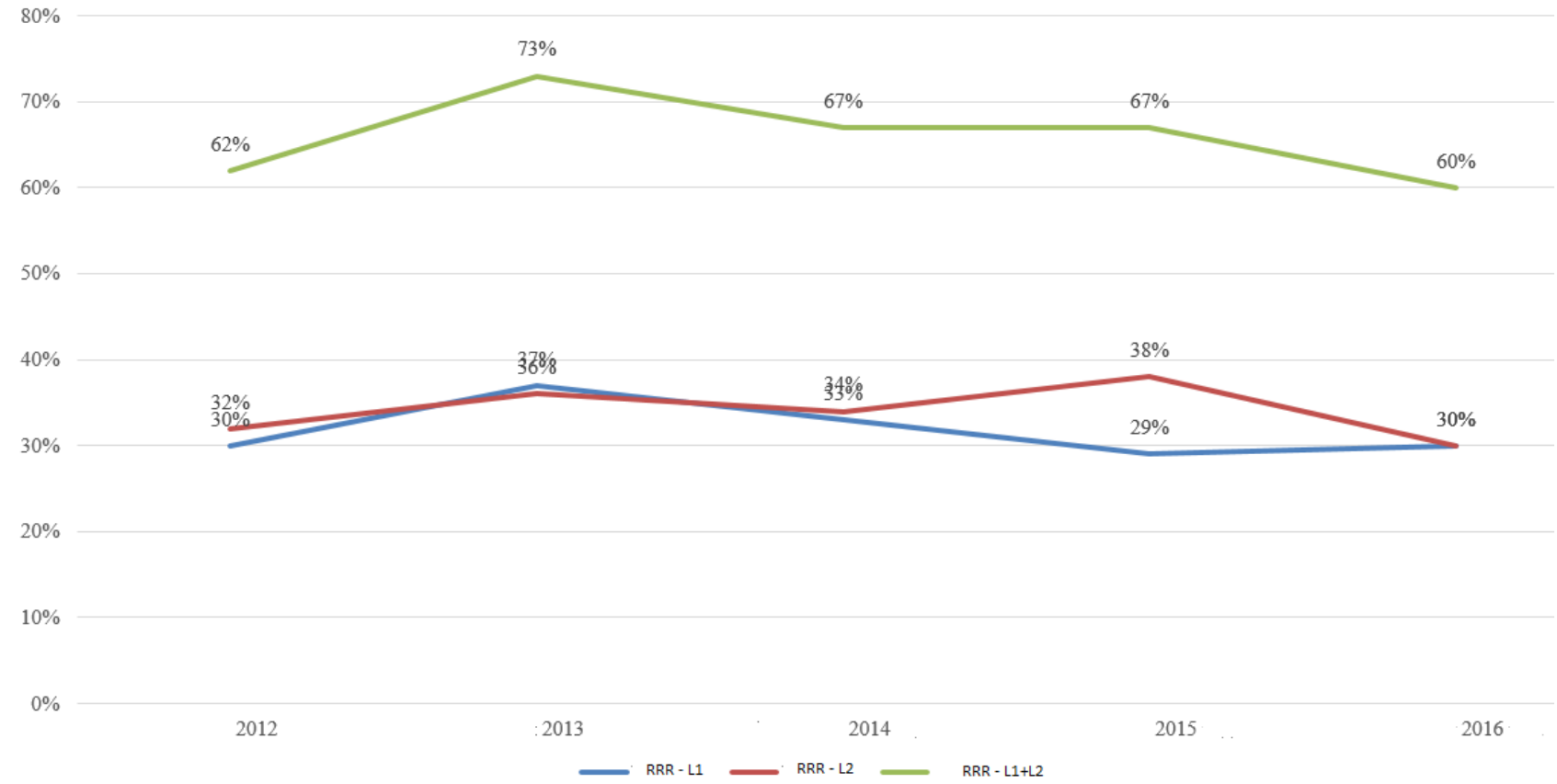

Fig. 4. Approximately $70 \%$ of tickets are solved remotely

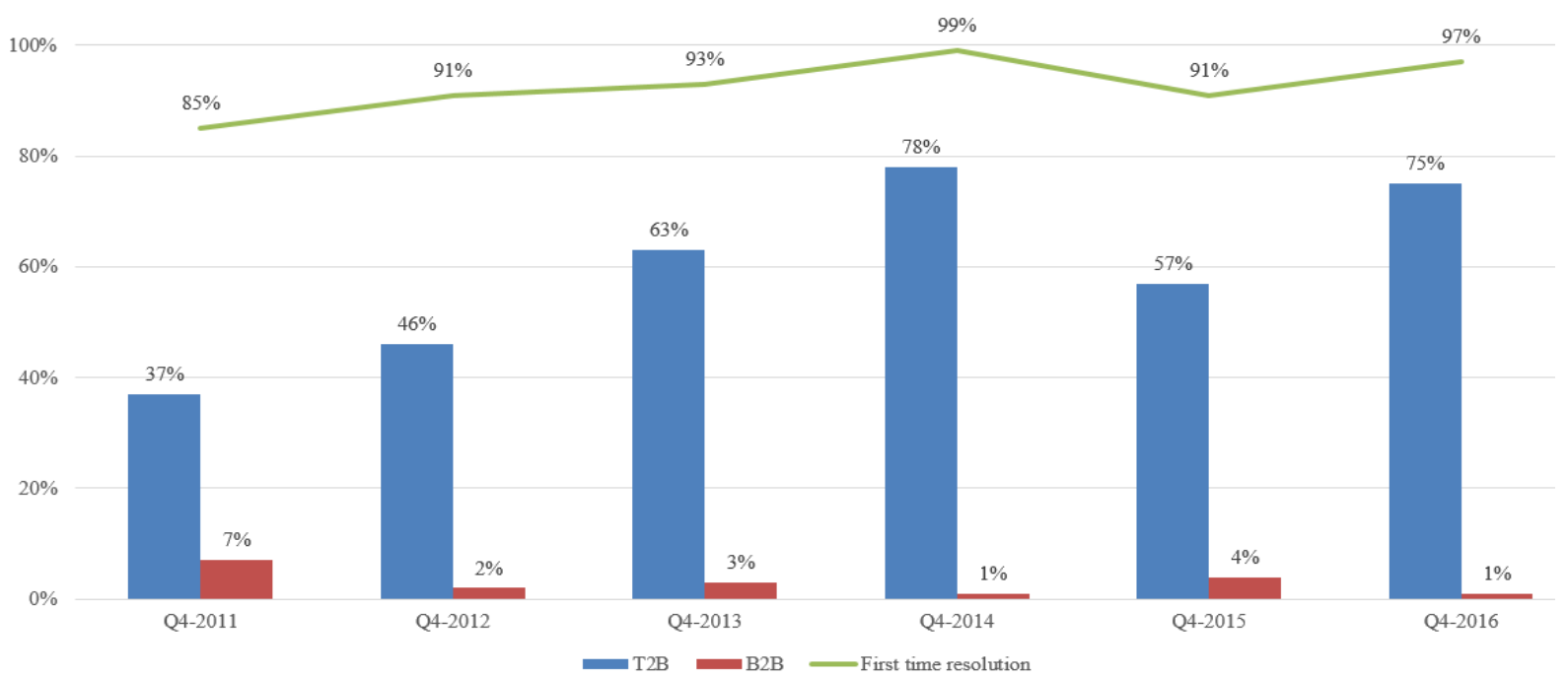

Fig. 5. Difference between satisfied and dissatisfied users, percentage of tickets resolved after the first visit 


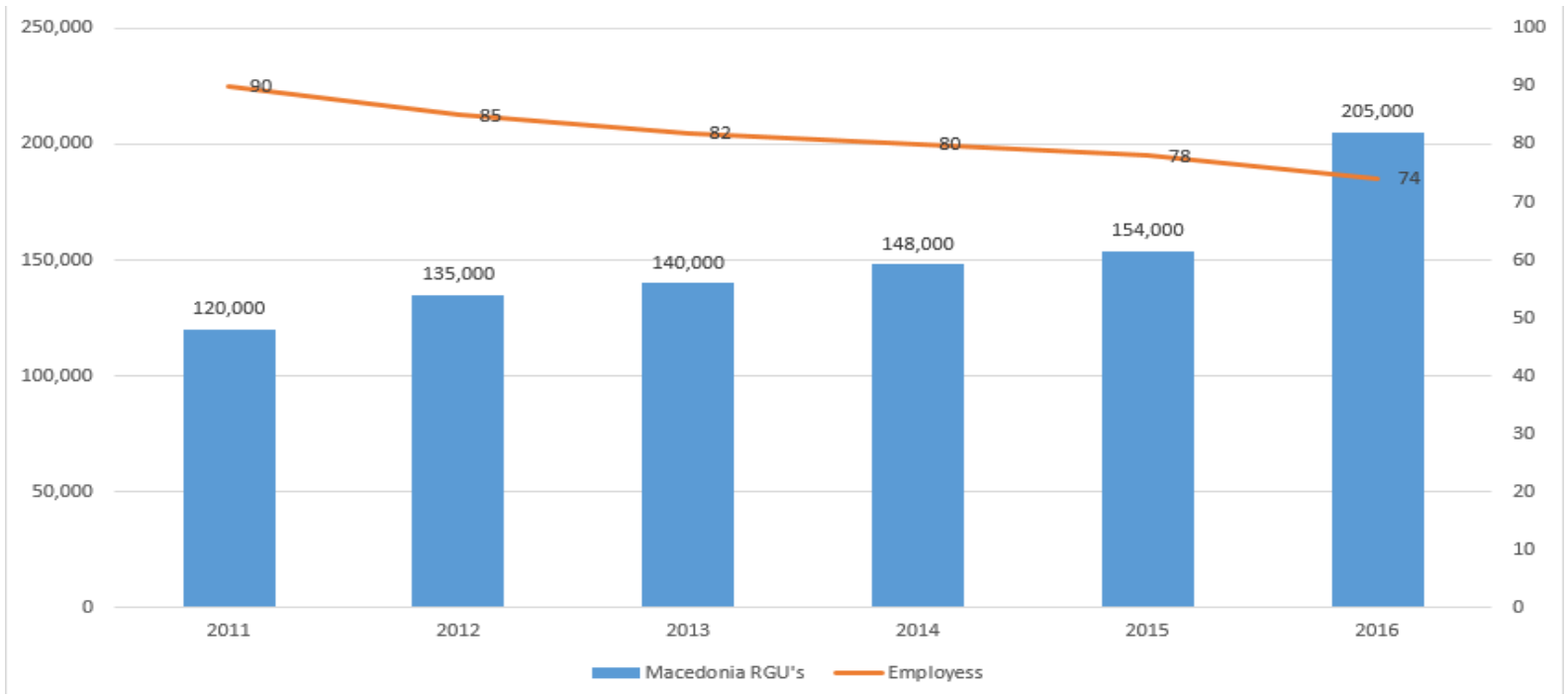

Fig. 6. Increasing the number of RGUs, despite the constant reduction in the number of employees 
